\section{Kidney \\ Blood Pressure Research}

\title{
Partial Reversal of Tissue Calcification and Extension of Life Span following Ammonium Nitrate Treatment of Klotho- Deficient Mice
}

\author{
Christina B. Leibrock ${ }^{a, b} \quad$ Martina Feger ${ }^{a, b} \quad$ Jakob Voelkla,b Ursula Kohlhofer ${ }^{c}$ \\ Leticia Quintanilla-Martinez ${ }^{c}$ Makoto Kuro-o ${ }^{d}$ Florian Lang ${ }^{a, b}$
}

Departments of aCardiology \& Cardiovascular Medicine and bPysiology, 'Department of Pathology, Eberhard-Karls-University of Tübingen, Tübingen, Germany; ${ }^{d}$ Center for Molecular Medicine, Jichi Medical University, Yakushiji, Shimotsuke, Tochigi, Japan

\section{Key Words}

Calcification • Aging • Life span • Acidosis • Chronic kidney disease $\cdot$ Klotho $\cdot 1,25(\mathrm{OH})_{2} \mathrm{D}_{3} \cdot$ Phosphate $\cdot$ Calcium

\begin{abstract}
Background/Aims: Klotho is required for the inhibitory effect of FGF23 on $1,25(\mathrm{OH})_{2} \mathrm{D}_{3}$ formation and Klotho-hypomorphic mice $(\mathrm{kl} / \mathrm{kl})$ suffer from severe tissue calcification due to excessive $1,25(\mathrm{OH})_{2} \mathrm{D}_{3}$ formation with subsequent increase of $\mathrm{Ca}^{2+}$ and phosphate concentrations and stimulation of osteogenic signaling. The excessive tissue calcification dramatically accelerates aging and leads to premature death of the animals. Osteogenic signaling in those mice is disrupted by treatment with $\mathrm{NH}_{4} \mathrm{Cl}$, which prevents tissue calcification and early death of $\mathrm{kl} / \mathrm{kl}$ mice. The present study explored whether the beneficial effects of $\mathrm{NH}_{4} \mathrm{Cl}$ treatment could be mimicked by $\mathrm{NH}_{4} \mathrm{NO}_{3}$ treatment. Methods: The $\mathrm{kl} / \mathrm{kl}$ mice had free access to tap water either without or with addition of $\mathrm{NH}_{4} \mathrm{NO}_{3}(0.28 \mathrm{M})$ starting with the mating of the parental generation. Calcification of trachea, lung, kidney, stomach, heart and vessels was visualized by histology with von Kossa staining. Plasma phosphate concentration was determined utilizing photometry, blood gas and electrolytes utilizing a blood Gas and Chemistry Analysis System and plasma $1,25(\mathrm{OH})_{2} \mathrm{D}_{3}$ concentration with ELISA. Results: In untreated $k l / k l$ mice plasma $1,25(\mathrm{OH})_{2} \mathrm{D}_{3}$ and phosphate concentrations were elevated, and the mice suffered from marked calcification of all tissues analyzed. Untreated $\mathrm{kl} / \mathrm{kl}$ mice further suffered from respiratory acidosis due to marked lung emphysema. $\mathrm{NH}_{4} \mathrm{NO}_{3}$-treatment decreased both, blood $\mathrm{pCO}_{2}$ and $\mathrm{HCO}_{3}{ }^{-}$, decreased calcification of trachea, lung, kidney, stomach, heart and vessels and increased the life span of $\mathrm{kl} / \mathrm{kl}$ mice more than 1.7 -fold $\left({ }^{\lambda}\right)$ or 1.6 -fold ( $(+)$ without significantly affecting extracellular $\mathrm{pH}$ or plasma
\end{abstract}




\section{Kidney Blood Pressure Research}

Kidney Blood Press Res 2016;41:99-107

\begin{tabular}{l|l}
\hline DOI: 10.1159/000443411 & (C) 2016 The Author(s). Published by S. Karger AG, Base
\end{tabular}

Published online: February 16, 2016

www.karger.com/kb

concentrations of $1,25(\mathrm{OH})_{2} \mathrm{D}_{3^{\prime}} \mathrm{Ca}^{2+}$, phosphate, $\mathrm{Na}^{+}$, and $\mathrm{K}^{+}$. Conclusions: $\mathrm{NH}_{4} \mathrm{NO}_{3}$-treatment turns respiratory acidosis into metabolic acidosis and mitigates calcification thus leading to a substantial extension of $k l / k l$ mice survival.

(C) 2016 The Author(s)

Published by S. Karger AG, Basel

\section{Introduction}

The protein klotho is required for the inhibitory effect of FGF23 on 25-hydroxyvitamin $\mathrm{D}_{3}$ 1- $\alpha$-hydroxylase (1- $\alpha$-hydroxylase) and thus 1,25-dihydroxyvitamin $\mathrm{D}_{3}\left(1,25(\mathrm{OH})_{2} \mathrm{D}_{3}\right)$ production [1]. Klotho may further up-regulate renal epithelial $\mathrm{Ca}^{2+}$ channels [2] and downregulate renal tubular phosphate transport [3]. Klotho-hypomorphic mice $(\mathrm{kl} / \mathrm{kl})$ suffer from severe tissue calcification leading to profound growth deficit, premature appearance of several age related disorders and dramatic shortening of life span $[1,4]$. Conversely, murine life span is extended by klotho overexpression [5]. In humans, klotho gene variants similarly impact on ageing and life span [6].

Chronic kidney disease (CKD) similarly leads to tissue calcification [7] with negative impact on life span [8]. In CKD tissue calcification is primarily a consequence of impaired phosphate excretion but is compounded by klotho deficiency [9] and affected by a klotho gene variant [10]. Vascular calcification is driven by an active pathophysiological process [11] with transition of vascular smooth muscle cells into an osteo- and chondrogenic phenotypes [12]. Osteogenic reprogramming is stimulated by hyperphosphatemia [13] and hyperaldosteronism [14].

CKD patients and $\mathrm{kl} / \mathrm{kl}$ mice further suffer from acidosis $[15,16]$, which may counteract $\mathrm{CaHPO}_{4}$ precipitation $[17,18]$. Along those lines, tissue calcification of $\mathrm{kl} / \mathrm{kl}$ mice could be prevented by induction of acidosis with acetazolamide [18]. In theory the acidosis could be aggravated by $\mathrm{NH}_{4}{ }^{+}$intake $[19,20] . \mathrm{NH}_{4}{ }^{+}$may further dissociate to $\mathrm{H}^{+}$and the cell membrane permeable $\mathrm{NH}_{3}$, which enters acidic compartments [21], binds $\mathrm{H}^{+}$and is thus trapped as $\mathrm{NH}_{4}{ }^{+}$in those compartments [22] $\mathrm{H}^{+}$binding of $\mathrm{NH}_{3}$ is followed by alkalinization of the acidic cellular compartments [23].

Treatment of $\mathrm{kl} / \mathrm{kl}$ mice with $\mathrm{NH}_{4} \mathrm{Cl}$ halts tissue calcification and thus leads to reversal of growth deficit and marked increase of life span [24], effects attributed in large part to disruption of osteogenic signaling due to alkalinization of acidic cellular compartments [24]. The present study explored whether $\mathrm{NH}_{4} \mathrm{NO}_{3}$ is similarly able to favorably influence tissue calcification and survival of $\mathrm{kl} / \mathrm{kl}$ mice.

\section{Materials and methods}

Mice

All animal experiments were conducted according to German law for the welfare of animals and were approved by local authorities. Male and female klotho-hypomorphic mice $(\mathrm{kl} / \mathrm{kl})$ were compared to male and female wild-type mice (WT). The origin of the mice, breeding and genotyping were described previously [4]. The mice had access to either tap water or a solution of $\mathrm{NH}_{4} \mathrm{NO}_{3}(0.28 \mathrm{M})$ in tap water ad libitum and were fed a standard chow diet (Sniff, Soest, Germany). The $\mathrm{NH}_{4} \mathrm{NO}_{3}$ treatment started with the mating of the parental generation and was maintained from pregnancy and weaning until analysis of the mice. The offspring was separated from the mothers at the age of four weeks.

\section{Blood and urinary chemistry}

To obtain blood specimens, animals were lightly anesthetized and about $50-200 \mu$ l of blood was withdrawn into heparinized capillaries by puncturing the retro-orbital plexus. The plasma phosphate concentrations were determined utilizing a photometric method (FUJI FDC 3500i, Sysmex, Norsted, Germany). Blood gas and electrolyte analysis as well as the measurement of ionized calcium was performed with the EDAN 15 Blood Gas and Chemistry Analysis System (EDAN Instruments, Shenzen, China). An ELISA kit was employed to determine plasma 1,25(OH)-vitamin $\mathrm{D}_{3}$ concentration (IDS, Boldon, UK) [25]. 


\section{Kidney Blood Pressure Research}
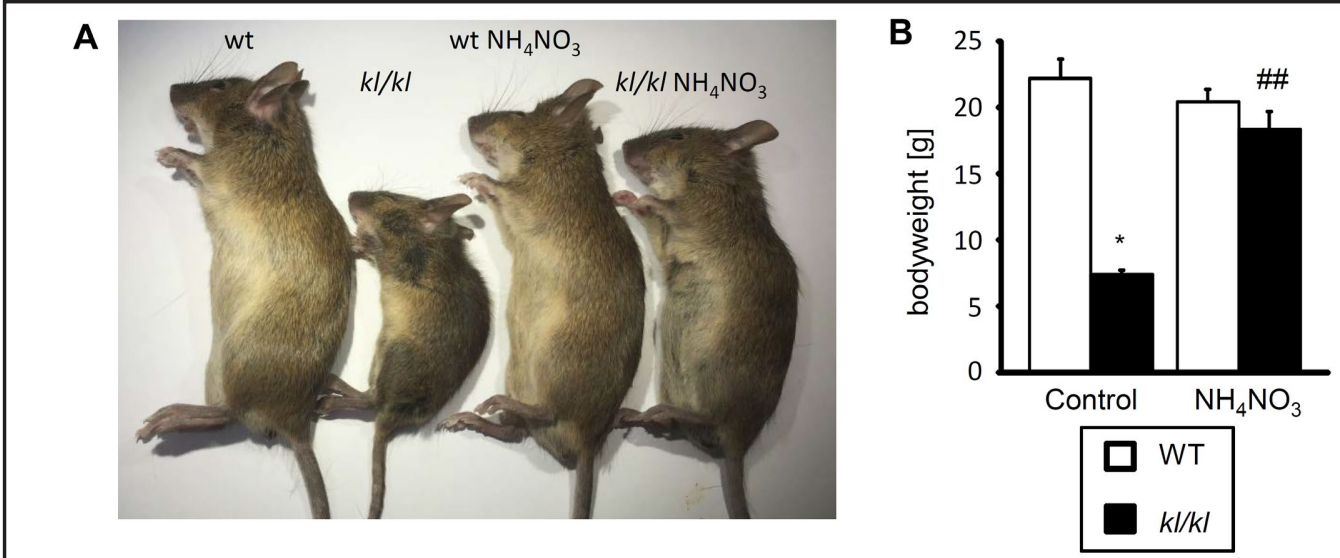

Fig. 1. Effect of $\mathrm{NH}_{4} \mathrm{NO}_{3}$ treatment on body weight of $\mathrm{kl} / \mathrm{kl}$ mice. A. Photograph of wild-type mice (WT) as well as klotho-hypomorphic mice $(\mathrm{kl} / \mathrm{kl})$ without (left) and with (right) $\mathrm{NH}_{4} \mathrm{NO}_{3}$ treatment $(0.28 \mathrm{M}$ in tap water). $\mathrm{B}$. Arithmetic means \pm SEM ( $n=5-9$ ) of body weight of wild-type mice (WT, white bars) and klotho-hypomorphic mice $\left(\mathrm{kl} / \mathrm{kl}\right.$, black bars) without (Control, left bars) and with $\left(\mathrm{NH}_{4} \mathrm{NO}_{3}\right.$, right bars) $\mathrm{NH}_{4} \mathrm{NO}_{3}$ treatment $(0.28$ $\mathrm{M}$ in tap water). ${ }^{*}(\mathrm{p}<0.05)$ indicates statistically significant differences from respective WT mice; \#\#(p< 0.01 ) indicates statistically significant differences from respective untreated mice.

\section{Histology}

For histological analysis of trachea, lung, kidney, stomach, heart and vessels, tissues from male $\mathrm{kl} / \mathrm{kl}$ mice (age 8 weeks) with or without treatment with $\mathrm{NH}_{4} \mathrm{NO}_{3}(0.28 \mathrm{M}$ in drinking water) were embedded in paraffin, cut in 2-3 $\mu$ m sections and stained with hematoxylin and eosin (H\&E) and von Kossa [26].

\section{Statistics}

Data are provided as means \pm SEM, $n$ represents the number of independent experiments. All data were tested for significance using ANOVA followed by posthoc analysis. For the life span experiments, SAS Jmp version 8.0.1 (SAS Institute Inc., Cary, NC, USA) was used. Only results with $p<0.05$ were considered statistically significant.

\section{Results}

The present study explored whether $\mathrm{NH}_{4} \mathrm{NO}_{3}$ treatment ( $0.28 \mathrm{M}$ in tap water) influenced growth deficit, tissue calcification and survival of klotho-hypomorphic $(\mathrm{kl} / \mathrm{kl})$ mice. As shown in Fig. 1A, $\mathrm{kl} / \mathrm{kl}$ mice were markedly smaller than corresponding wild-type mice (WT). Accordingly, the body weight was significantly less in $\mathrm{kl} / \mathrm{kl}$ mice than in wild-type mice (Fig. 1B). Following $\mathrm{NH}_{4} \mathrm{NO}_{3}$ treatment $(0.28 \mathrm{M}$ in tap water), the body weight of $\mathrm{kl} / \mathrm{kl}$ mice was significantly increased. Following $\mathrm{NH}_{4} \mathrm{NO}_{3}$ treatment the body weight was thus not significantly different between $\mathrm{kl} / \mathrm{kl}$ mice and wild-type mice.

As illustrated in Fig, 2A, plasma $1,25(\mathrm{OH})_{2} \mathrm{D}_{3}$ concentration was significantly higher in $\mathrm{kl} /$ $\mathrm{kl}$ mice than in wild-type mice, a difference not significantly affected by $\mathrm{NH}_{4} \mathrm{NO}_{3}$ treatment. Similarly, plasma phosphate concentration was significantly higher in $\mathrm{kl} / \mathrm{kl}$ mice than in wildtype mice, a difference again not significantly affected by treatment with $\mathrm{NH}_{4} \mathrm{NO}_{3}$ (Fig. 2B). Blood ionized $\mathrm{Ca}^{2+}$ was again significantly higher in untreated $\mathrm{kl} / \mathrm{kl}$ mice than in untreated wildtype mice, a difference again not significantly modified by $\mathrm{NH}_{4} \mathrm{NO}_{3}$ treatment (Fig. 2C). There were no differences in blood $\mathrm{Na}^{+}$levels (Fig. 2D) between $\mathrm{kl} / \mathrm{kl}$ mice and wild-type mice and between untreated and $\mathrm{NH}_{4} \mathrm{NO}_{3}$ treated animals. Plasma $\mathrm{K}^{+}$concentration was significantly lower in untreated $\mathrm{kl} / \mathrm{kl}$ mice than in untreated wild-type mice (Fig. 2E), a difference abolished 


\section{Kidney \\ Blood Pressure \\ Research}
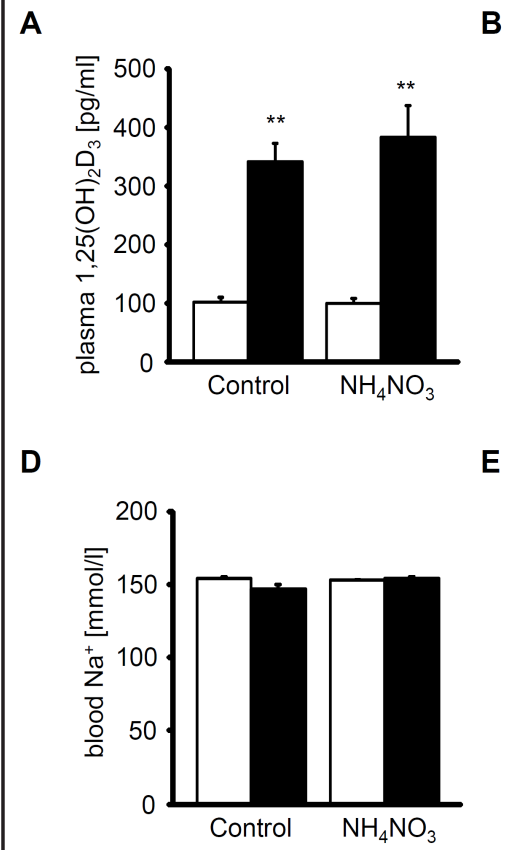

B

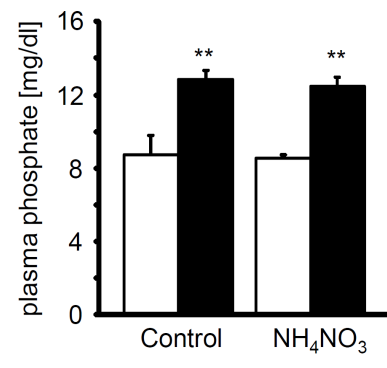

E
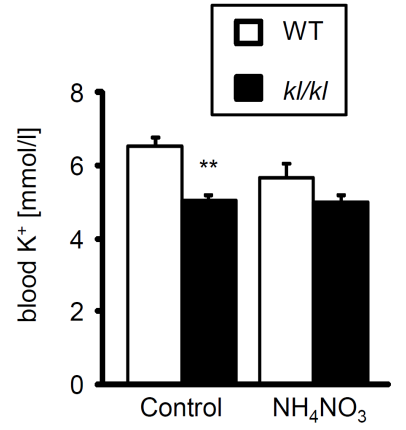

C

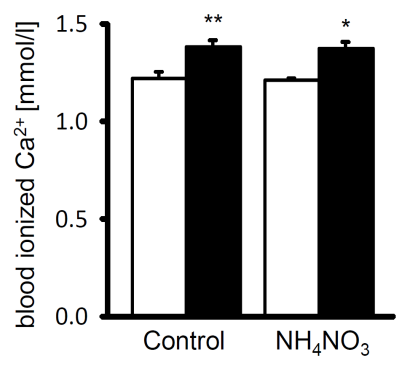

$\mathbf{F}$

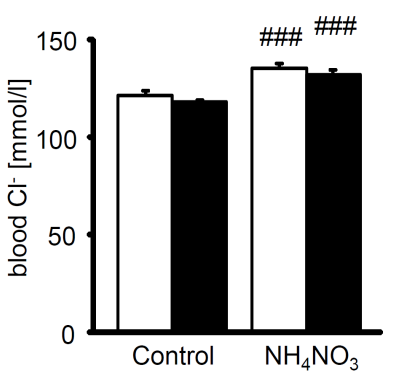

Fig. 2. Plasma $1,25(\mathrm{OH})_{2} \mathrm{D}_{3}$ phosphate, $\mathrm{Ca}^{2+}, \mathrm{Na}^{+}, \mathrm{K}^{+}$, and $\mathrm{Cl}^{-}$concentrations of wild-type mice and $\mathrm{kl} / \mathrm{kl}$ mice with or without $\mathrm{NH}_{4} \mathrm{NO}_{3}$ treatment. Arithmetic means \pm SEM of plasma (A) $1,25(\mathrm{OH})_{2} \mathrm{D}_{3}(\mathrm{n}=7)$, (B) phosphate ( $\mathrm{n}=4-9)$, (C) ionized $\mathrm{Ca}^{2+}(\mathrm{n}=10)$, (D) $\mathrm{Na}^{+}(\mathrm{n}=10)$, (E) $\mathrm{K}^{+}(\mathrm{n}=10)$, and (F) $\mathrm{Cl}^{-}(\mathrm{n}=10)$ concentrations of wildtype mice ( $W T$, white bars) and klotho-hypomorphic mice ( $k l / k l$, black bars) without (Control, left bars) and with $\left(\mathrm{NH}_{4} \mathrm{NO}_{3}\right.$, right bars) $\mathrm{NH}_{4} \mathrm{NO}_{3}$ treatment $\left(0.28 \mathrm{M}\right.$ in tap water). ${ }^{*}(\mathrm{p}<0.05),{ }^{* *}(\mathrm{p}<0.01)$ indicate statistically significant differences from respective WT mice; \#\#\#( $p<0.001)$ indicate statistically significant differences from respective untreated mice.

by $\mathrm{NH}_{4} \mathrm{NO}_{3}$ treatment. There were no differences in blood $\mathrm{Cl}^{-}$concentrations between $\mathrm{kl} / \mathrm{kl}$ mice and wild-type mice (Fig. 2F). $\mathrm{NH}_{4} \mathrm{NO}_{3}$ treatment significantly increased blood Cl- concentrations in both, $\mathrm{kl} / \mathrm{kl}$ mice and wild-type mice (Fig. $2 \mathrm{~F}$ ).

As illustrated in Fig. 3A, blood pH was lower in untreated $\mathrm{kl} / \mathrm{kl}$ mice than in untreated wild-type mice. $\mathrm{NH}_{4} \mathrm{NO}_{3}$ treatment significantly decreased blood $\mathrm{pH}$ in wild-type mice. $\mathrm{NH}_{4} \mathrm{NO}_{3}$ treatment tended to decrease blood $\mathrm{pH}$ in $\mathrm{kl} / \mathrm{kl}$ mice, an effect, however, not reaching statistical significance (Fig. 3A). As shown in Fig. 3B, blood $\mathrm{pCO}_{2}$ was significantly increased in $\mathrm{kl} / \mathrm{kl}$ mice and significantly decreased to normal values under treatment with $\mathrm{NH}_{4} \mathrm{NO}_{3}$. Plasma $\mathrm{HCO}_{3}^{-}$concentration was significantly higher in untreated $\mathrm{kl} / \mathrm{kl}$ mice than in untreated wildtype mice, a difference again significantly blunted by $\mathrm{NH}_{4} \mathrm{NO}_{3}$ treatment (Fig. $3 \mathrm{C}, \mathrm{D}$ ).

Histology was employed to visualize tissue calcification and histopathology in untreated and $\mathrm{NH}_{4} \mathrm{NO}_{3}$ treated male $\mathrm{kl} / \mathrm{kl}$ mice. As illustrated in Fig. 4, excessive calcification was observed in trachea, lung, kidney, and stomach of $\mathrm{kl} / \mathrm{kl}$ mice. Moreover, histology revealed marked emphysema of lung tissue from $\mathrm{kl} / \mathrm{kl}$ mice. $\mathrm{NH}_{4} \mathrm{NO}_{3}$ treatment strongly reduced the tissue calcification and reversed the emphysema of $\mathrm{kl} / \mathrm{kl}$ mice. As shown in Fig. 5, excessive calcifications were similarly observed in cardiac and vascular tissue of untreated $\mathrm{kl} / \mathrm{kl}$ mice. Again, $\mathrm{NH}_{4} \mathrm{NO}_{3}$ treatment blunted the calcification of cardiac and vascular tissue from $\mathrm{kl} / \mathrm{kl}$ mice.

As illustrated in Fig, 6, $\mathrm{NH}_{4} \mathrm{NO}_{3}$ treatment was followed by a substantial and significant (Log-Rang $\mathrm{p}<0.0004$; Wilcoxon $\mathrm{p}<0.0016$ ) increase of the life span of male $\mathrm{kl} / \mathrm{kl}$ mice. Half of untreated $\mathrm{kl} / \mathrm{kl}$ mice survived 72 days and half of the $\mathrm{NH}_{4} \mathrm{NO}_{3}$ treated $\mathrm{kl} / \mathrm{kl}$ mice survived 122 days. Accordingly, $\mathrm{NH}_{4} \mathrm{NO}_{3}$ treatment extended the median life span of $\mathrm{kl} / \mathrm{kl}$ mice by a factor of 1.7. 


\section{Kidney Bloód Pressure Research}

Fig. 3. $\mathrm{Blood} \mathrm{pH}, \mathrm{pCO}_{2}, \mathrm{HCO}_{3}{ }^{-}$ act. and $\mathrm{HCO}_{3}{ }^{-}$std. concentrations of wild-type mice and $\mathrm{kl} / \mathrm{kl}$ mice with or without $\mathrm{NH}_{4} \mathrm{NO}_{3}$ treatment. Arithmetic means \pm SEM $(n=10)$ of blood (A) $\mathrm{pH},(\mathrm{B}) \mathrm{pCO}_{2},(\mathrm{C})$ actual $\mathrm{HCO}_{3}^{-}$and (D) $\mathrm{HCO}_{3}^{-}$ standardized to normal $\mathrm{CO}_{2}$, in wild-type mice (WT, white bars) and klotho-hypomorphic mice $(k l / k l$, black bars) without (Control, left bars) and with $\left(\mathrm{NH}_{4} \mathrm{NO}_{3}\right.$, right bars) $\mathrm{NH}_{4} \mathrm{NO}_{3}$ treatment $(0.28 \mathrm{M}$ in tap water). ${ }^{*}(\mathrm{p}<0.05),{ }^{* *}(\mathrm{p}$ $<0.01$ ) indicate statistically significant differences from respective $W T$ mice; \#( p $<0.05)$, \#\#( $\mathrm{p}<0.01)$ indicate statistically significant differences from respective untreated mice.
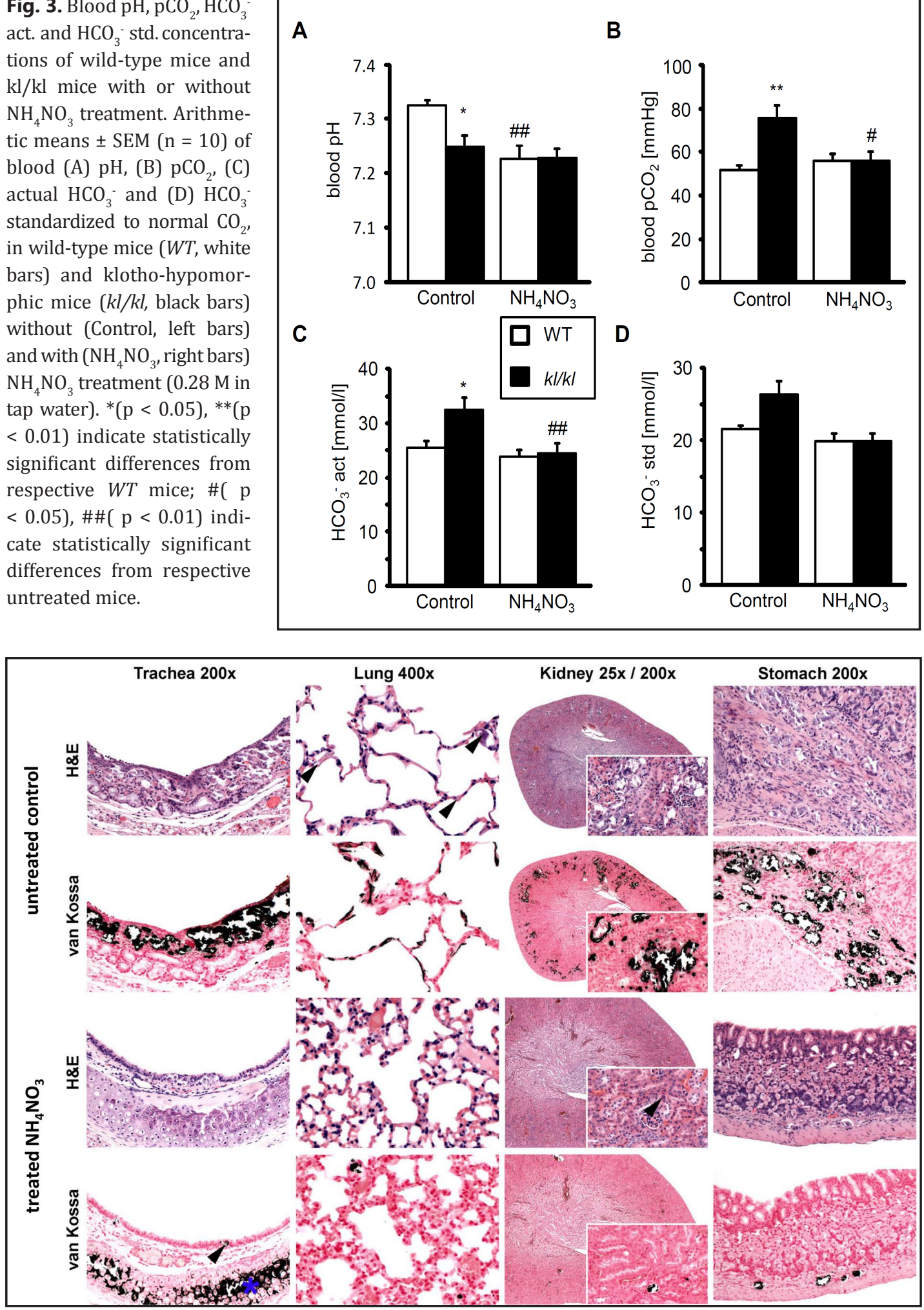

Fig. 4. $\mathrm{NH}_{4} \mathrm{NO}_{3}$ treatment counteracts soft tissue calcification in $\mathrm{kl} / \mathrm{kl}$ mice. H\&E and von Kossa staining of trachea, lung, kidney, and stomach from male klotho-hypomorphic mice without (untreated, upper panel) and with (treated, lower panel) $\mathrm{NH}_{4} \mathrm{NO}_{3}$ treatment ( $0.28 \mathrm{M}$ in tap water). The results are representative for three $\mathrm{kl} / \mathrm{kl}$ mice per group. Arrowheads indicate the calcifications; Asterisk indicates the cartilage. 


\section{Kidney Blood Pressure Research}

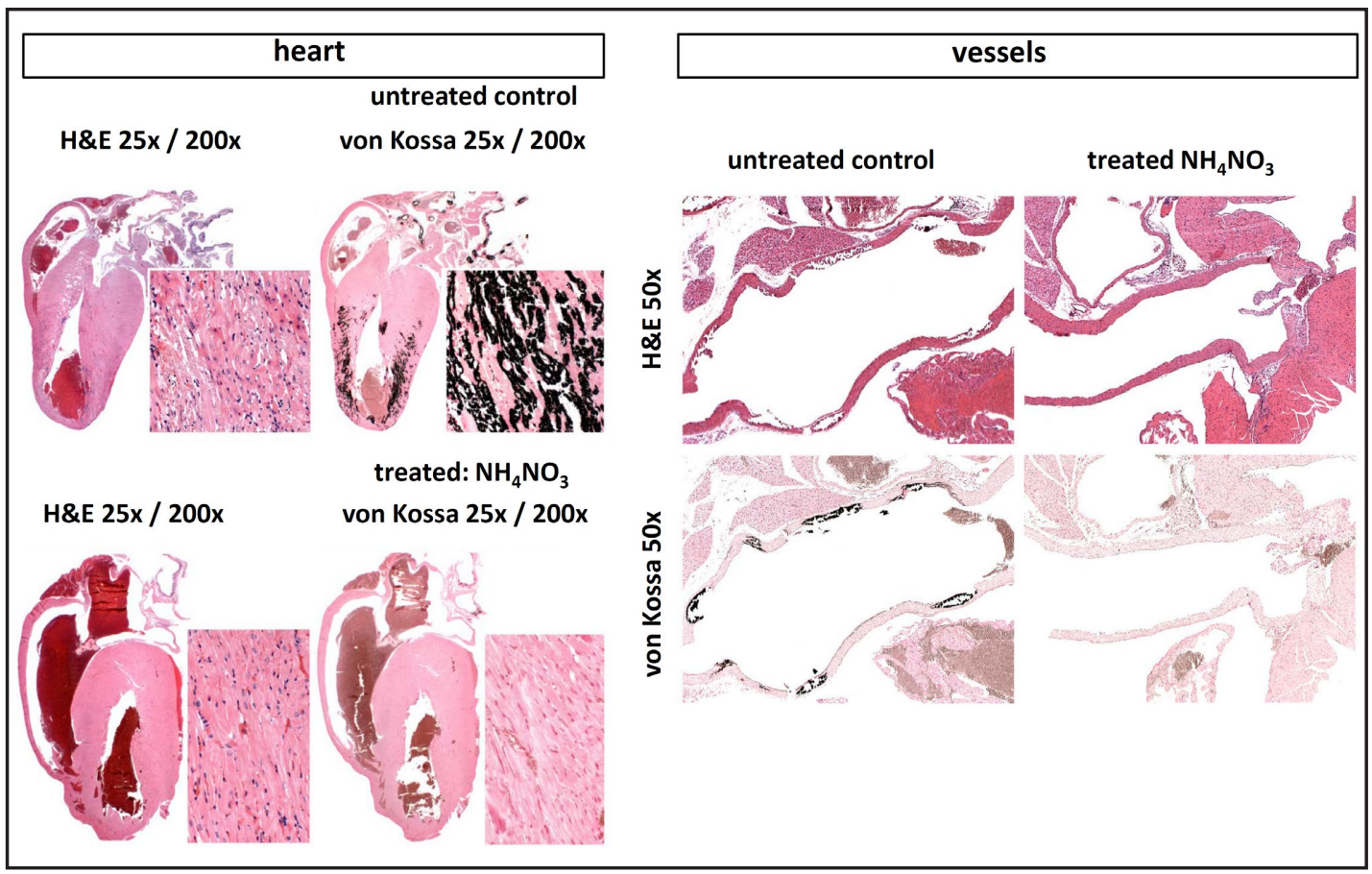

Fig. 5. $\mathrm{NH}_{4} \mathrm{NO}_{3}$ treatment counteracts cardiac and vascular calcification in $\mathrm{kl} / \mathrm{kl}$ mice. $\mathrm{H} \& \mathrm{E}$ and von Kossa staining of cardiac and vascular tissue from male klotho-hypomorphic mice without (untreated, upper panel) and with (treated, lower panel) $\mathrm{NH}_{4} \mathrm{NO}_{3}$ treatment ( $0.28 \mathrm{M}$ in tap water). The results are representative for three $\mathrm{kl} / \mathrm{kl}$ mice per group.

Fig. 6. Effect of $\mathrm{NH}_{4} \mathrm{NO}_{3}$ on life span of kl/kl mice. Percentage of surviving male klotho-hypomorphic mice $(k l / k l)$ maintained on control diet without treatment (closed circles) and with $\mathrm{NH}_{4} \mathrm{NO}_{3}$ treatment $(0.28$ $\mathrm{M}$ in tap water, open circles) as a function of age. Survival of $\mathrm{kl} / \mathrm{kl}$ mice was significantly extended by $\mathrm{NH}_{4} \mathrm{NO}_{3}$ treatment (Log-Rang ( $\mathrm{p}<0.0004$, Wilcoxon $\mathrm{p}<0.0016 ; \mathrm{n}=7$ - 9).

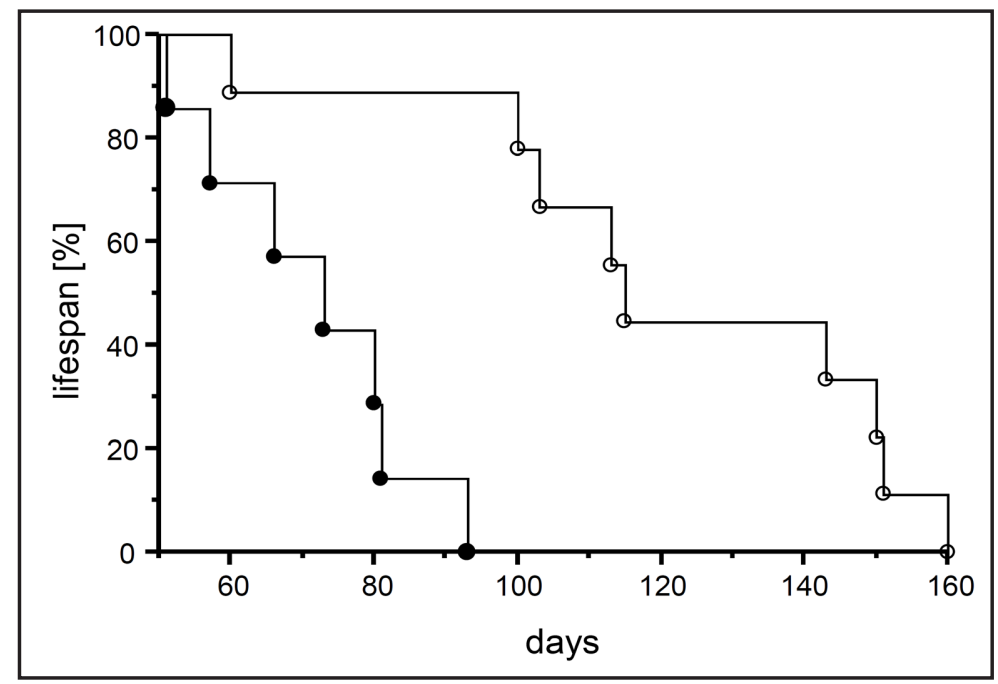

\section{Discussion}

The present study confirms the phenotype of $\mathrm{kl} / \mathrm{kl}$ mice, i.e. the severe tissue calcification, growth deficit and accelerated aging presumably resulting from unrestricted formation of $1,25(\mathrm{OH})_{2} \mathrm{D}_{3}$ with subsequent marked increase of $\mathrm{Ca}^{2+}$ and phosphate concentrations leading to triggering of osteogenic signaling [1]. The present study further reveals that $\mathrm{NH}_{4} \mathrm{NO}_{3}$ treatment mitigates tissue calcification of $\mathrm{kl} / \mathrm{kl}$ mice, leading to almost complete reversal of growth deficit, attenuation of tissue injury and substantial extension of life span. All those 


\section{Kidney \\ Blood Pressure Research}

Kidney Blood Press Res 2016;41:99-107

\begin{tabular}{l|l}
\hline DOI: 10.1159/000443411 & (c 2016 The Author(s). Published by S. Karger AG, Base
\end{tabular}

effects mimic those of $\mathrm{NH}_{4} \mathrm{Cl}$ treatment, which has previously been shown to disrupt the excessive osteogenic signaling of $\mathrm{kl} / \mathrm{kl}$ mice [24].

The tissue calcification of $\mathrm{kl} / \mathrm{kl}$ mice is most likely due to excessive extracellular phosphate concentrations, which are known to stimulate osteogenic signaling and vascular calcification [13], which is in turn a hallmark of aging [7, 27-29]. Along those lines plasma phosphate concentration is a determinant of mortality [30]. $\mathrm{NH}_{4} \mathrm{NO}_{3}$ treatment mitigates tissue calcification in $\mathrm{kl} / \mathrm{kl}$ mice without significantly modifying plasma $1,25(\mathrm{OH})_{2} \mathrm{D}_{3}, \mathrm{Ca}^{2+}$ and phosphate concentrations. $\mathrm{NH}_{4} \mathrm{NO}_{3}$ treatment is further effective despite virtually constant extracellular $\mathrm{pH}$, another determinant of calcification [18, 31-33].

$\mathrm{NH}_{4} \mathrm{NO}_{3}$ treatment does not aggravate the acidosis of $\mathrm{kl} / \mathrm{kl} \mathrm{mice,} \mathrm{which} \mathrm{is} \mathrm{due} \mathrm{to} \mathrm{excessive}$ $\mathrm{pCO}_{2}$ presumably due to the severe lung emphysema (Fig. 4). The $\mathrm{NH}_{4} \mathrm{NO}_{3}$ treatment reverses the hypercapnia presumably by counteracting the development of lung emphysema (Fig. 4). At the same time, however, $\mathrm{NH}_{4} \mathrm{NO}_{3}$ treatment decreases plasma bicarbonate concentration, presumably due to partial incorporation of $\mathrm{NH}_{4}^{+}$into urea, a metabolic pathway consuming $\mathrm{HCO}_{3}^{-}$[34]. Following $\mathrm{NH}_{4} \mathrm{NO}_{3}$ treatment bicarbonate and $\mathrm{pCO}_{2}$ decline in parallel leaving extracellular $\mathrm{pH}$ virtually unchanged. Accordingly, $\mathrm{NH}_{4} \mathrm{NO}_{3}$ treatment converts the respiratory acidosis of untreated $\mathrm{kl} / \mathrm{kl}$ mice into a metabolic acidosis.

Similar to the excessive osteogenic signaling in $\mathrm{kl} / \mathrm{kl}$ mice [24, 35], enhanced osteogenic signaling leads to vascular calcification in CKD patients [35, 36]. In CKD vascular calcification increases the risk for cardiovascular events [37], the leading cause of death in this clinical condition [38]. Similar to the osteogenic signaling in $\mathrm{kl} / \mathrm{kl}$ mice, osteogenic signaling in CKD patients [39] is secondary to hyperphosphatemia and is compounded by decrease of klotho expression [35]. Disruption of osteogenic reprogramming in vascular tissue is thus expected to favourably influence the clinical course of CKD [39].

\section{Conclusion}

Treatment with $\mathrm{NH}_{4} \mathrm{NO}_{3}$ decreases tissue and vascular calcification, reverses the growth deficit and substantially extends the life span of klotho-hypomorphic mice despite continued increase of plasma $1,25(\mathrm{OH})_{2} \mathrm{D}_{3}, \mathrm{Ca}^{2+}$ and phosphate concentrations. In view of the previous observations following $\mathrm{NH}_{4} \mathrm{Cl}$ treatment, $\mathrm{NH}_{4} \mathrm{NO}_{3}$ treatment is presumably effective by disrupting osteogenic signaling.

\section{Disclosure Statement}

The authors state that they do not have any conflicts of interest to disclose.

\section{Acknowledgements}

The authors acknowledge the technical assistance of Dennis Thiele, Elfriede Faber and the meticulous preparation of the manuscript by Tanja Loch. The study was supported by the Deutsche Forschungsgemeinschaft (DFG 315/15-1).

\section{References}

1 Kuro-o M: Klotho, phosphate and FGF-23 in ageing and disturbed mineral metabolism. Nat Rev Nephrol 2013;9:650-660. 


\section{Kidney \\ Blood Pressure Research}

Kidney Blood Press Res 2016;41:99-107

\begin{tabular}{l|l}
\hline DOI: 10.1159/000443411 & (C) 2016 The Author(s). Published by S. Karger AG, Base
\end{tabular}

Published online: February 16, 2016

www.karger.com/kbr

2 Topala CN, Bindels RJ, Hoenderop JG: Regulation of the epithelial calcium channel TRPV5 by extracellular factors. Curr. Opin. Nephrol. Hypertens 2007;16:319-324.

3 Hu MC, Shi M, Zhang J, Pastor J, Nakatani T, Lanske B, Razzaque MS, Rosenblatt KP, Baum MG, Kuro-o M, Moe OW: Klotho: a novel phosphaturic substance acting as an autocrine enzyme in the renal proximal tubule. FASEB J 2010;24:3438-3450.

4 Kuro-o M, Matsumura Y, Aizawa H, Kawaguchi H, Suga T, Utsugi T, Ohyama Y, Kurabayashi M, Kaname T, Kume E, Iwasaki H, Iida A, Shiraki-Iida T, Nishikawa S, Nagai R, Nabeshima YI: Mutation of the mouse klotho gene leads to a syndrome resembling ageing. Nature 1997;390:45-51.

5 Kurosu H, Yamamoto M, Clark JD, Pastor JV, Nandi A, Gurnani P, McGuinness OP, Chikuda H, Yamaguchi M, Kawaguchi H, Shimomura I, Takayama Y, Herz J, Kahn CR, Rosenblatt KP, Kuro-o M: Suppression of aging in mice by the hormone Klotho. Science 2005;309:1829-1833.

6 Invidia L, Salvioli S, Altilia S, Pierini M, Panourgia MP, Monti D, De Rango F, Passarino G, Franceschi C: The frequency of Klotho KL-VS polymorphism in a large Italian population, from young subjects to centenarians, suggests the presence of specific time windows for its effect. Biogerontology 2010;11:67-73.

7 Shroff R, Long DA, Shanahan C: Mechanistic insights into vascular calcification in CKD. J Am Soc Nephrol 2013;24:179-189.

8 Staude H, Jeske S, Schmitz K, Warncke G, Fischer DC: Cardiovascular risk and mineral bone disorder in patients with chronic kidney disease. Kidney Blood Press Res 2013;37:68-83.

9 Hu MC, Kuro-o M, Moe OW: The emerging role of Klotho in clinical nephrology. Nephrol Dial Transplant 2012;27:2650-2657.

10 Friedman DJ, Afkarian M, Tamez H, Bhan I, Isakova T, Wolf M, Ankers E, Ye J, Tonelli M, Zoccali C, Kuro-o M, Moe 0, Karumanchi SA, Thadhani R: Klotho variants and chronic hemodialysis mortality. J Bone Miner Res 2009;24:1847-1855.

11 Mizobuchi M, Towler D, Slatopolsky E: Vascular calcification: the killer of patients with chronic kidney disease. J Am Soc Nephrol 2009;20:1453-1464.

12 Steitz SA, Speer MY, Curinga G, Yang HY, Haynes P, Aebersold R, Schinke T, Karsenty G, Giachelli CM: Smooth muscle cell phenotypic transition associated with calcification: upregulation of $\mathrm{Cbfa} 1$ and downregulation of smooth muscle lineage markers. Circ Res 2001;89:1147-1154.

13 Giachelli CM: Vascular calcification: in vitro evidence for the role of inorganic phosphate. J Am Soc Nephrol 2003;14:S300-S304.

14 Voelkl J, Alesutan I, Leibrock CB, Quintanilla-Martinez L, Kuhn V, Feger M, Mia S, Ahmed MS, Rosenblatt KP, Kuro-o M, Lang F: Spironolactone ameliorates PIT1-dependent vascular osteoinduction in klothohypomorphic mice. J Clin Invest 2013;123:812-822.

15 Alexander RT, Woudenberg-Vrenken TE, Buurman J, Dijkman H, van der Eerden BC, van Leeuwen JP, Bindels RJ, Hoenderop JG: Klotho prevents renal calcium loss. J Am Soc Nephrol 2009;20:2371-2379.

16 Kovesdy CP: Metabolic acidosis and kidney disease: does bicarbonate therapy slow the progression of CKD? Nephrol Dial Transplant 2012;27:3056-3062.

17 Yonova D: Vascular calcification and metabolic acidosis in end stage renal disease. Hippokratia 2009;13:139-140.

18 Leibrock CB, Alesutan I, Voelkl J, Michael D, Castor T, Kohlhofer U, Quintanilla-Martinez L, Kubler L, Mannheim JG, Pichler BJ, Rosenblatt KP, Kuro-o M, Lang F: Acetazolamide sensitive tissue calcification and aging of klotho-hypomorphic mice. J Mol Med (Berl) 2016;94:95-106.

19 Nowik M, Kampik NB, Mihailova M, Eladari D, Wagner CA: Induction of metabolic acidosis with ammonium chloride (NH4Cl) in mice and rats--species differences and technical considerations. Cell Physiol Biochem 2010;26:1059-1072.

20 Mohebbi N, Perna A, van der Wijst J, Becker HM, Capasso G, Wagner CA: Regulation of two renal chloride transporters, AE1 and pendrin, by electrolytes and aldosterone. PLoS One 2013;8:e55286.

21 Roos A, Boron WF: Intracellular pH. Physiol Rev 1981;61:296-434.

22 Ling H, Ardjomand P, Samvakas S, Simm A, Busch GL, Lang F, Sebekova K, Heidland A: Mesangial cell hypertrophy induced by $\mathrm{NH} 4 \mathrm{Cl}$ : role of depressed activities of cathepsins due to elevated lysosomal $\mathrm{pH}$. Kidney Int 1998;53:1706-1712.

23 Volkl H, Friedrich F, Haussinger D, Lang F: Effect of cell volume on Acridine Orange fluorescence in hepatocytes. Biochem J 1993;295:11-14. 


\section{Kidney \\ Blood Pressure Research}

Kidney Blood Press Res 2016;41:99-107

\begin{tabular}{l|l}
\hline DOI: 10.1159/000443411 & (C) 2016 The Author(s). Published by S. Karger AG, Base
\end{tabular}

Published online: February 16, 2016 www.karger.com/kbr

24 Leibrock CB, Alesutan I, Voelkl J, Pakladok T, Michael D, Schleicher E, Kamyabi-Moghaddam Z, QuintanillaMartinez L, Kuro-o M, Lang F: NH4Cl Treatment Prevents Tissue Calcification in Klotho Deficiency. J Am Soc Nephrol 2015;26:2423-2433.

25 Feger M, Mia S, Pakladok T, Nicolay JP, Alesutan I, Schneider SW, Voelkl J, Lang F: Down-regulation of renal klotho expression by Shiga toxin 2. Kidney Blood Press Res 2014;39:441-449.

26 Mossbrugger I, Hoelzlwimmer G, Calzada-Wack J, Quintanilla-Martinez L: Standardized morphological phenotyping of mouse models of human diseases within the German Mouse Clinic. Verh Dtsch Ges Pathol 2007;91:98-103.

27 Kapustin A, Shanahan CM: Targeting vascular calcification: softening-up a hard target. Curr Opin Pharmacol 2009;9:84-89.

28 Peacock M: Calcium metabolism in health and disease. Clin J Am Soc Nephrol 2010;5:S23-S30.

29 Weissen-Plenz G, Nitschke Y, Rutsch F: Mechanisms of arterial calcification: spotlight on the inhibitors. Adv Clin Chem 2008;46:263-293.

30 Tonelli M, Sacks F, Pfeffer M, Gao Z, Curhan G: Relation between serum phosphate level and cardiovascular event rate in people with coronary disease. Circulation 2005;112:2627-2633.

31 Jara A, Felsenfeld AJ, Bover J, Kleeman CR: Chronic metabolic acidosis in azotemic rats on a high-phosphate diet halts the progression of renal disease. Kidney Int 2000;58:1023-1032.

32 Mendoza FJ, Lopez I, Montes dO, Perez J, Rodriguez M, Aguilera-Tejero E: Metabolic acidosis inhibits soft tissue calcification in uremic rats. Kidney Int 2008;73:407-414.

33 Jara A, Chacon C, Ibaceta M, Valdivieso A, Felsenfeld AJ: Effect of ammonium chloride and dietary phosphorus in the azotaemic rat. I. Renal function and biochemical changes. Nephrol Dial Transplant 2004;19:1986-1992.

34 Guder WG, Haussinger D, Gerok W: Renal and hepatic nitrogen metabolism in systemic acid base regulation. J Clin Chem Clin Biochem 1987;25:457-466.

35 Hu MC, Shi M, Zhang J, Quinones H, Griffith C, Kuro-o M, Moe OW: Klotho deficiency causes vascular calcification in chronic kidney disease. J Am Soc Nephrol 2011;22:124-136.

36 Moe SM, Drueke T, Lameire N, Eknoyan G: Chronic kidney disease-mineral-bone disorder: a new paradigm. Adv Chronic Kidney Dis 2007;14:3-12.

37 London GM, Guerin AP, Marchais SJ, Metivier F, Pannier B, Adda H: Arterial media calcification in end-stage renal disease: impact on all-cause and cardiovascular mortality. Nephrol Dial Transplant 2003;18:17311740 .

38 Foley RN, Parfrey PS, Sarnak MJ: Epidemiology of cardiovascular disease in chronic renal disease. J Am Soc Nephrol 1998;9:S16-S23.

39 Koleganova N, Piecha G, Ritz E, Schirmacher P, Muller A, Meyer HP, Gross ML: Arterial calcification in patients with chronic kidney disease. Nephrol Dial Transplant 2009;24:2488-2496. 